
ФГБОУ ВО «Ангарский государственный технический университет», e-mail: joke6@bk.ru НОВЫЕ ПРАВИЛА ПО ОХРАНЕ ТРУДА - 2021

\title{
NEW LABOR PROTECTION REGULATIONS-2021
}

Semshikov S.E.

Аннотация. Рассмотрены правила по охране труда, введенные в действие в 2021 году. Указаны основные изменения в связи с вступлением в силу новых требований.

Ключевые слова: охрана труда, вредные и опасные производственные факторы.

Abstract. The rules on labor protection, introduced in 2021 , are considered. The main changes in connection with the entry into force of the new requirements are indicated.

Keywords: labor protection, harmful and dangerous production factors.

Постановлением Правительства Российской Федерации № 2467 и в соответствии с требованиями Трудового кодекса РФ $[1,2]$ признаны утратившими силу и отменены целый ряд нормативных правовых актов в области охраны труда Правительства РФ, фредеральных органов исполнительной власти, правовых актов исполнительных и распорядительных органов государственной власти РСФСР и СССР (Всего 1275 документов).

С 1 января 2021 года вступили в силу новые правила по охране труда в строительстве, промышленности, сельском хозяйстве, медицине, на транспорте [1-12] (всего 40 документов).

В строительстве приняты новые правила по охране труда при строительстве, реконструкции и ремонте, при производстве дорожных строительных и ремонтно-строительных работ, при строительстве, реконструкции, ремонте и содержании мостов, при электросварочных, газосварочных и окрасочных работах, при производстве строительных материалов, при погрузочно-разгрузочных работах и размещении грузов [3-8].

При погрузочно-разгрузочных работах работодатель обязан обеспечить идентификацию опасностей и оценку профессионального риска. При организации выполнения работ, связанных с воздействием на работников вредных производственных факторов, работодатель обязан принять меры по их исключению или снижению до уровней допустимого воздействия. При невозможности исключения или снижения уровней вредных производственных факторов до уровней допустимого воздействия в связи с характером и условиями производственного процесса проведение работ без обеспечения работников соответствующими специальной одеждой, специальной обувью и другими средствами индивидуальной защиты запрещается [3].

Погрузочно-разгрузочные работы с применением грузоподъемных кранов выполняются по технологическим регламентам (технологическим картам, проектам производства работ). Погрузка и разгрузка грузов массой от 50 кг до 500 
кг должна производиться с применением грузоподъемного оборудования и устройств (тельферов, лебедок, талей, блоков). Ручная погрузка и разгрузка таких грузов допускается под руководством лица, ответственного за безопасное производство работ, и при условии, что нагрузка на одного работника не будет превышать 50 кг.

При окрасочных работах работодателем разрабатываются инструкции по охране труда для профессий и видов выполняемых работ. Работодатель обязан обеспечить безопасность окрасочных работ, содержание оборудования в исправном состоянии, обучение работников по охране труда и проверку знаний требований охраны труда, контроль за соблюдением работниками требований инструкций. Окрасочные работы должны выполняться на специальных установках, в камерах или на площадках, оборудованных общеобменной приточновытяжной и местной вытяжной вентиляцией. В помещениях для работы с лакокрасочными материалами, в местах хранения опасных и вредных веществ должны быть вывешены знаки безопасности с поясняющими надписями [5].

В промышленности действуют новые правила по охране труда при работе на высоте, при размещении, монтаже, техническом обслуживании и ремонте технологического оборудования, при работе в целлюлозно-бумажной, лесохимической, легкой промышленности, при работе с инструментом и приспособлениями, при нанесении металлопокрытий, при выполнении работ в лесозаготовительном, деревообрабатывающем производствах, производстве цемента, при эксплуатации электроустановок [4, 11].

Правила по охране труда при эксплуатации электроустановок устанавливают государственные нормативные требования охраны труда при эксплуатации электрооборудования, предназначенного для производства, преобразования, трансформации, передачи, распределения электрической энергии и преобразования ее в другой вид энергии. Работники обязаны проходить обучение безопасным методам и приемам выполнения работ в электроустановках, оказанию первой помощи пострадавшему на производстве. Электротехнический персонал кроме обучения оказанию первой помощи пострадавшему на производстве должен быть обучен приемам освобождения пострадавшего от действия электрического тока с учетом специфики обслуживаемых электроустановок. Специалисты по охране труда, контролирующие электроустановки организаций потребителей электроэнергии, должны иметь группу IV по электробезопасности, их производственный стаж (не обязательно в электроустановках) должен быть не менее 3 лет.

При работе на высоте работодатель должен провести оценку профрессиональных рисков, связанных с возможным падением работника с высоты в соответствии с классификацией работ на высоте. Работы, отнесенные работодателем к работам на высоте, должны быть учтены в локальных документах. Работодатель определяет необходимость и периодичность проверки знаний 
безопасных методов и приемов работы для каждой категории работников 3 группы работ на высоте. Экзамен проводится комиссиями, создаваемыми приказом руководителя организации. Состав комиссий для приема экзамена у работников, допускаемых к проведению работ на высоте, выполняемых с оформлением наряда-допуска, формируется из работников 3 группы. Лицо, ответственное за организацию и безопасное проведение работ на высоте, обязано организовать разработку документации по охране труда при работах на высоте, плана мероприятий по эвакуации и спасению работников при возникновении аварийной ситуации и при проведении спасательных работ, разработку технологических карт, оформление нарядов-допусков. Наряды-допуски, работы по которым полностью закончены, должны храниться в течение 30 суток. Периодическое обучение работников 1 и 2 групп безопасным методам и приемам выполнения работ на высоте осуществляется не реже 1 раза в 3 года. Периодическое обучение работников 3 группы безопасным методам и приемам выполнения работ на высоте осуществляется не реже 1 раза в 5 лет. Требования к работникам 3 группы по безопасности работ на высоте: старше 21 года, опыт выполнения работ на высоте более 2-х лет [4].

На транспорте вступили в силу новые правила по охране труда на морских судах и судах внутреннего водного транспорта, при транспортировании и реализации нефтепродуктов, на городском электрическом транспорте, на автомобильном, промышленном и железнодорожном транспорте [6, 8, 12].

Правила по охране труда на автомобильном транспорте устанавливают государственные нормативные требования охраны труда при организации и проведении работ, связанных с техническим содержанием и эксплуатацией автомобильного транспорта [6]. При направлении водителя в длительный рейс работодатель обязан провести инструктаж по охране труда водителю перед выездом об условиях работы на линии и особенностях перевозимого груза.

При мойке транспортных средств не направлять струю воды на электроприборы, людей. При добавлении моющих веществ использовать защитные перчатки. Испытание и опробование тормозов транспортного средства на ходу проводятся на предназначенных для этого площадках.

При техническом обслуживании и ремонте городского электротранспорта запрещается пользоваться открытым огнем и курить [8]. Скорость движения городского электротранспорта на территории парка (депо) не должна превышать 5 км/ч, а в помещениях и на осмотровых канавах - 3 км/ч, кроме случаев испытания ходовой части и тормозной системы.

Новые правила труда действуют в медицинских организациях [13]. При организации медицинской деятельности работодатель обязан оценивать профессиональные риски, связанные с возможным причинением вреда здоровью работника в процессе его трудовой деятельности. 
К вредным и опасным факторам трудового процесса в медицинских организациях относятся биологические, химические, фризические фракторы, в том числе угроза жизни и здоровью работников, связанная с возможным совершением в отношении них противоправных действий со стороны пациентов, их родственников, тяжесть и напряженность трудового процесса.

Работники, связанные с проведением рентгенологических исследований, проходят обучение по радиационной безопасности и по правилам работы с источниками ионизирующего излучения. К самостоятельной работе в рентгенодиагностических отделениях допускаются лица, прошедшие специальную подготовку и отнесенные приказом по организации к соответствующей категории персонала (А и Б).

К работе в отделениях радионуклидной диагностики и лучевой терапии допускаются лица не моложе 18 лет, прошедшие специальную подготовку и отнесенные приказом к соответствующей категории персонала (А и Б).

В новых правилах работодателю допускается применять оборудование, обеспечивающее дистанционную видеофиксацию процессов производства работ, допускается возможность ведения документооборота в области охраны труда в электронном виде с использованием электронной подписи [3, 5, 10, 13].

При выполнении работ повышенной опасности допускается оформление и выдача наряда-допуска на производство работ в электронно-цифровом виде.

Работодатель может устанавливать дополнительные требования безопасности, не противоречащие правилам. Требования охраны труда должны содержаться в соответствующих инструкциях по охране труда, доводиться до работника в виде распоряжений, указаний, инструктажа $[2,3,13]$.

Согласно требованиям Трудового кодекса РФ, работодатель обязан обеспечить наличие комплекта нормативных правовых актов (НПА), содержащих требования охраны труда в соответствии со спецификой своей деятельности, определить, какие изменения НПА коснулись предприятия, организовать необходимые виды обучения персонала для внеочередной проверки знаний, определить перечень локальных НПА для внесения изменений, отмены или разработки новых инструкций по охране труда.

\section{ЛИТЕРАТУРА}

1. Трудовой кодекс Российской Федерации" от 30.12.2001 N 197-Ф3 (ред. от 20.04.2021) [Текст]. - М.: Омега - Л., 2021. —296 с.

2. Федеральный закон от 31.07.2020 N 247-Ф3 «Об обязательных требованиях в Российской Федерации» [Текст]. - М.: ИПС законодательство России, 2020. -28c.

3. Приказ Минтруда России от 28.10.2020 № 753н «Об утверждении правил по охране труда при погрузочно-разгрузочных работах и размещении гру- 
зов» [Текст]. - М.: Официальный интернет-портал правовой информации, 2020. -34 c.

4. Приказ Минтруда России от 16.11.2020 № 782н «Об утверждении правил по охране труда при работе на высоте» [Текст]. - М.: Официальный интернет-портал правовой информации, 2020. - 87 с.

5. Приказ Минтруда России от 02.12.2020 № 849н «Об утверждении правил по охране труда при выполнении окрасочных работ» [Текст]. - М.: Официальный интернет-портал правовой информации, 2020. - 17 с.

6. Приказ Минтруда России от 09.12.2020 № 871н «Об утверждении правил по охране труда на автомобильном транспорте» [Текст]. - М.: Официальный интернет-портал правовой информации, 2020. - 38 с.

7. Приказ Минтруда России от 09.12.2020 № 872н «Об утверждении правил по охране труда при строительстве, реконструкции, ремонте и содержании мостов» [Текст]. - М.: Официальный интернет-портал правовой информации, 2020. -48 c.

8. Приказ Минтруда России от 09.12.2020 № 875н «Об утверждении правил по охране труда на городском электрическом транспорте» [Текст]. - М.: Офрициальный интернет-портал правовой информации, 2020. - 52 с.

9. Приказ Минтруда России от 11.12.2020 N 883н «Об утверждении правил по охране труда при строительстве, реконструкции и ремонте» [Текст]. М.: Официальный интернет-портал правовой информации, 2020. - 62 с.

10. Приказ Минтруда России от 11.12.2020 № 884н «Об утверждении правил по охране труда при электросварочных и газосварочных работах» [Текст]. - М.: Официальный интернет-портал правовой информации, 2020. 26c.

11. Приказ Минтруда России от 15.12.2020 № 901н «Об утверждении правил по охране труда при производстве строительных материалов» [Текст]. - М.: Официальный интернет-портал правовой информации, 2020. - 66 с.

12. Приказ Минтруда России от 15.12.2020 № 903н «Об утверждении правил по охране труда при эксплуатации электроустановок» [Текст]. - М.: Официальный интернет-портал правовой информации, 2020. - 130 с.

13. Приказ Минтруда России от 18.12.2020 № 928н «Об утверждении правил по охране труда в медицинских организациях» [Текст]. - М.: Официальный интернет-портал правовой информации, 2020. - 48 с. 